\title{
УДК 027.7:378.4:7]:37.091.33-027.22:793.7
}

DOI: http://dx.doi.org/10.18524/2304-1447.2019.2(22).180377

\author{
Скаченко Олена Олексіївна, \\ завідувачка сектору методичної роботи \\ Наукової бібліотеки Київського національного \\ університету культури і мистецтв \\ вул. Свгена Коновальця, 36, м. Київ, 01133, Україна \\ тел.: (044) 529-98-34 \\ e-mail: skachenko.nana@ukr.net \\ ORCID: 0000-0003-3827-5985
}

\section{ВИКОРИСТАННЯ ІГРОВОЇ МОДЕЛІ ГЕЙМІФІКАЦЇ̈ У СОЦІОКУЛЬТУРНІЙ ДІЯЛЬНОСТІ БІБЛІОТЕК}

\begin{abstract}
У статті актуалізовано тренд використання ігрових механік у соціокультурній та просвітницькій діяльності бібліотек. Визначено коло українських та зарубіжних дослідників застосування ігрових технологій у навчанні. Розкрито методологію, стратегію, форми, мотиваційні функції, характеристики та аспекти процесу гейміфікації.

Опираючись на досвід Наукової бібліотеки КНУКіМ здійснено характеристику можливостей застосування ігрової моделі гейміфікації у соціокультурній діяльності бібліотек на прикладі проведення Інформаційних ігор.

3'ясовано особливості інтерактивної платформи Kahoot зі створення вікторин, опитувань, дискусій. Окреслено перспективи застосування гейміфікації у соціокультурній діяльності бібліотек.

Встановлено, що застосування гейміфікації у бібліотечній галузі має переваги, серед яких: масштабність заходів; налагодження нових форм комунікації $з$ користувачами; формування кола «друзів бібліотеки», заохочення до вивчення культури і мистецтва України та світу.
\end{abstract}

Ключові слова: гейміфікація, ігрова механіка, бібліотеки, інформаційні ігри, веб-вікторини, Kahoot.

Ігри можна використовувати щуоб робити людей розумнішими. ГейбЗікерманн

Постановка проблеми. Застосування інформаційних технологій у навчальній, освітній діяльності; розвиток ефективних напрямків взаємодії бібліотек закладів вищої освіти та студентської молоді викликають необхідність пошуку інноваційних моделей комунікаційного спілкування. Використання ігрових механік, у т. ч. комп'ютерних, для залучення користувачів до проведення бібліотечних заходів $\epsilon$ сучасним трендом.

Упродовж останніх п'яти років стрімкого розвитку набула технологія гейміфікації (від англ. gamification, геймізація, ігрофікація). Мотивуючи до участі 
у грі, вона перетворює нудні процеси навчання чи/або рутинної діяльності на привабливі, цікаві та пізнавальні.

Аналіз останніх досліджень та публікацій. Певний час гейміфікація розглядалася як маркетинговий та рекламний інструмент у статтях блогерів та SMM-менеджерів В. Богданова, М. Грінберга, О. Дядікової, А. Полянського, О. Хлопкової, A. Yurgelenas та ін. Відомі приклади успішного використання переваг гейміфікації в освітній діяльності, зокрема для вивчення іноземних мов, історії, літератури, математики, фізики. Питання застосування ігрових технологій геймізації в навчальному процесі досліджували В. Бугаєва, К. Бугайчук, В. Бузько, Б. М. Качан, В. Кухаренко, О. Рибалко, А. Столяревська, О. Ткаченко та ін. Технологію ігропедагогіки вивчає і практично втілює у вигляді навчальних ігор і тренінгів А. Комісаров. Геймізацію як спосіб формування мотивації студентів розглядали Л. Сергеєва, Д. Кларк, О. Свплова. Ключовими зарубіжними дослідниками теорії ігрових механік є Кевін Вербах (Kevin Werbach), Ден Хантер (Dan Hunter), Джейн МакГонігал (Jane McGonigal), Гал Рімон (Gal Rimon), Гейб Зікерманн (Gabe Zichermann), Джоселін Ліндер (Joselin Linder), Ю Кай Чоу (Yu-Kai Chou).

Актуальність дослідження використання ігрових моделей гейміфікації у соціокультурній діяльності випливає з того, що серед вітчизняних науковців інформаційно-бібліотечної галузі питання гейміфікації бібліотечної діяльності не стало предметом спеціальних досліджень.

Мета дослідження. Зважаючи на необхідність пошуку нових креативних форматів взаємодії бібліотек та користувачів, у дослідженні ставимо за мету вивчити особливості, окреслити перспективи застосування гейміфікації у соціокультурній діяльності бібліотек, опираючись на досвід Наукової бібліотеки КНУКіМ із використання можливостей інтерактивної платформи Kahoot.

Виклад основного матеріалу. Під впливом цифрових технологій відбувається швидка трансформація інформаційної сфери загалом, ролі працівників бібліотек і потреб користувачів. Як визнає О. Онищенко, на часі актуальним $€$ «формування у бібліотечного працівника стилю мислення і поведінки на основі категорій і понять цифрової культури, не ігноруючи культури рукописного та друкованого слова. Бібліотечне мислення потребує масштабного інноваційного насичення» $[9$, с. 4].

О. Ю. Мар'їна, розглядаючи інформаційно-комунікаційну взаємодію як фактор розвитку бібліотечних систем зазначає, що «прогрес цифрових технологій докорінно змінює логіку функціонування та розвиток сучасної бібліотеки, трансформує не лише іï фонди, ресурси, технології, сервіси, а й фізичний простір. Виникають нові формати роботи бібліотек» [7].

Елементи ігрових механік вже достатньо активно використовуються в управлінні персоналом, з маркетинговими, освітніми, екологічними, оздоровчими цілями. Тому, метою застосування гейміфікації у бібліотечні справі $€$ залучення нових користувачів, активація співпраці студентів та бібліотеки 
університету. За допомогою ігрових технологій студенти набувають нових навичок спілкування, які вони ігнорували при одноманітному перебігу навчального процесу.

Опрацювання джерел $[1,3,5,12,14]$ дозволило виявити:

- підвищувати продуктивність праці працівників через використання ігрових елементів запропонував Чарльз Кунрадт (Charles Coonradt) у книзі «Робота як гра» «The Game of Work» (1973);

- вперше термін «гейміфікація» застосував британський програміст, розробник комп’ютерних ігор Нік Пеллінг (NickPelling) (2002);

- популярна ігрофікована соціальна мережа з функцією геопозиціювання Foursquare 3'явилася у 2009 році;

- методологію геймізації у бізнесі від 2012 року розробляє Кевін Вербах (Kevin Werbach), автор онлайн-курсу «Gamification» на платформі електронного навчання Coursera;

- відмінність геймізації від власне гри полягає у використанні ігрової механіки для того, щоб нудне чи одноманітне завдання зробити цікавим;

- стратегія гейміфікації базується на отриманні винагороди за виконані завдання;

- гейміфікація здатна змінювати поведінку, сприяє формуванню нових соціальних норм.

Зарубіжні та вітчизняні дослідники пропонують різні визначення поняття гейміфікації. Описуючи використання елементів гри в неігровому середовищі, Г. Зікерманн визначає гейміфікацію як процес використання ігрового механізму й мислення з метою збільшення аудиторії і розв'язання проблем [15].

I. Самойлова гейміфікацію (ігрофікацію) розглядає як «процес використання ігрового мислення і динаміки ігор для залучення аудиторії і вирішення завдань, перетворення чого-небудь в гру» [10].

На мотиваційній функції гейміфікації та її компонентів, що дозволяє активізувати діяльність людей акцентують увагу К. Вербах та Д. Хантер [1].

Тобто, більшість дослідників схильні розглядати гейміфікацію загалом як застосування підходів, характерних для комп'ютерних ігор, для неігрових процесів $з$ метою залучення користувачів і споживачів до вирішення прикладних завдань.

Оскільки бібліотеки закладів вищої освіти працюють на перетині освітньої, навчальної, просвітницької, мистецької системи координат, важливо враховувати завдання гейміфікації в освітньому процесі, що полягає у прагненні «використати схильність людини до гри як ключ до залучення у процеси обміну та отримання інформації» [2, с. 49].

Стосовно поєднання гейміфікації і бібліотечної діяльності, на нашу думку, більше підходять визначення Alex Yurgelenas: «гейміфікація - це мистецтво запозичення усіх кумедних та захоплюючих елементів ігор і застосування їх у реальній або виробничій діяльності» [13] та Іллі Курильова «гейміфікація -це 
спроба світу змінитися, адаптуватися під нових людей та їхній спосіб життя. Успішно конкурувати, бути ефективним, бути цікавим, бути вартим уваги. Увага нині дорого коштує» [5].

Джейн МакГонігал у книзі «Реальність під питанням. Чому ігри роблять нас кращими і як вони можуть змінити світ» («Reality Is Broken: Why Games Make us Better and How they Can Change the World») пропонує виділяти 4 характерні риси гри. Вона повинна мати [6]:

- чіткі цілі для забезпечення мотивації учасників;

- логічні і послідовні правила і обмеження для досягнення поставлених цілей;

- систему зворотного зв'язку, яка демонструє гравцям, наскільки вони близькі до мети, ілюструє, що правила дотримуються, а цілі -досяжні;

- добровільну згоду на участь, прийняття правил та їх дотримання.

Гейміфікація може варіюватися і набувати трьох форм [11]:

- як змагання, де присутні ігрові елементи: зрозумілі цілі, правила, турнірні таблиці;

- як гра без переможця (Win-win game, безпрограшна гра), що цікава самим процесом;

- як естетика, метою якої $є$ візуалізація завдань (навчання, результатів роботи тощо).

Крім інновацій, маркетингу, мотивації користувачів/працівників, виділяють інші галузі застосування гейміфікації: тренінги, соціальні мережі, здоровий спосіб життя.

Аналіз змісту, форм, методик гейміфікації актуалізує можливість застосування його ігрових технологій у соціокультурній діяльності бібліотек. Враховуючи, що геймізація загалом передбачає використання елементів гри, ігрових технологій у неігровому контексті, то геймізацію бібліотечної діяльності ми розглядаємо як використання ігрових практик, технік і власне, ігор у бібліотеці 3 просвітницькою метою/цілями/завданнями.

Відомі приклади застосування гейміфікації в інформаційно-бібліотечній сфері. У 2011 p. Національна бібліотека Фінляндії запропонувала усім бажаючим долучитися до збереження культурної спадщини країни, взявши участь у волонтерському розважально-ігровому проекті Digitalkoot. Цифрова платформа, розроблена компанією Microtask, пропонує он-лайн гру, учасники-гравці якої виконують завдання обробки (перевірки слів) оцифрованих сторінок історичних книг, періодичних видань $з$ архівів бібліотеки.

Елементи гейміфікації можуть застосовуватися у різних формах бібліотечної роботи. Оскільки бібліотека закладу вищої освіти працює із студентською молоддю, основними цілями та очікуваними результатами геймізації бібліотечного соціокультурного простору стали зміни у рутинній поведінці користувачів, організація їхньої спільної діяльності, розвиток критичного мислення, стрес стійкості, уміння швидко приймати рішення. 
У науковій бібліотеці Київського національного університету культури і мистецтв (НБ КНУКіМ) гейміфікацію комунікаційного простору розпочали із проведення освітніх вікторин, пов'язаних із змістом навчального процесу.

Так, у жовтні 2018 р. в бібліотеці були започатковані Інформаційні ігри (у форматі брейн-рингу), що передбачали проведення інтелектуальних вікторин, ігрових та практичних завдань за тематикою роботи відділів бібліотеки та колом питань, дотичних до туристичної сфери. Учасниками ігор стали студенти 1 курсу кафедр міжнародного туризму та музеєзнавства і експертизи історикокультурних пам'яток.

При розробці сценарію Інформаційних ігор враховувалися основні аспекти геймізаиії [8]:

- Динаміка - передбачає розробку ігор із постійним зосередженням уваги гравців та проявів реакції у реальному часі;

- Механіка - використання елементів ігрового процесу (зворотній зв'язок, миттєві нагороди, бали, таблиця результатів);

- Естетика - створення позитивного ігрового настрою, емоційного піднесення;

- Соціальна взаємодія - використання техніки гри, що передбачає взаємодію, підтримку, співпереживання тощо.

Учасникам команд було запропоновано 5 різнопланових завдань:

- Вікторина «60 секунд: хто знає більше про музеї і визначні пам’ятки світу» (за 60 секунд необхідно правильно відповісти на більшу кількість питань);

- Гра: «Систематизація книг про подорожі від А до Я» (потрібно було швидко і вірно скласти запропоновані 15 книг за абеткою);

- Гра: «Хто такий Фантаз?» (передбачала пошук заданих слів у словниках/енциклопедіях і пояснення їх значення аудиторіi);

- Вікторина «Туристичні атракції України та світу: факти, рекорди» (учасники команд відповідали на 15 питань, обираючи вірну відповідь із 4 запропонованих);

- Гра «Столичне пенальті» (команди по-черзі називали країну, суперники мали назвати іï столицю).

Як видно із переліку, в якості елементів гри було обрано декілька цілей. Це дозволило гравцям, при пошуку та формулюванні відповідей, побачити один в одного риси дослідника, професора-знавця, лідера тощо. Крім того, вже саме змістове наповнення ігрових завдань сприяло розширенню меж знань студентів про туристичні дестинації та музейні скарби України і світу.

Постановку завдань, пояснення правил, підтримку динаміки гри, контроль ігрових дій виконувала модератор (автор-розробник сценарію та наповнення ігор). Контроль за дотриманням ігрових правил, здійснення підрахунку балів, нагородження переможців здійснювала суддівська колегія. Атмосферу суперництва, шалене емоційне забарвлення у вигляді гасел і речівок, дозволені під- 
казки, забезпечували групи підтримки. Блогери від обох команд вели пряму відеотрансляцію на сторінках бібліотеки у Facebook та акаунтах учасників в Instagram.

При проведенні Інформаційних ігор були використані такі елементи гейміфікації як: миттєві призи, бали за перемогу у певному конкурсі/грі, індикатори стану гри. За підсумками, команда переможців отримала солодкі «золоті медалі» та бейджі переможців.

Наступним кроком застосування гейміфікації стало створення тематичних веб-вікторин. Щоб у студентів виникла добровільна мотивація взяти участь у вікторині, було використано поєднання пізнавальних (пов'язаних із вивченням певної дисципліни) та соціальних (командні змагання) мотивів.

Розробка вікторини - креативний процес, у якому ідеї, задумки, знання автора-модератора складають базову основу успіху. Цифрові технології пропонують величезний перелік інструментів для їхнього створення. Нами було випробувано платформи H5P, Genial.ly, Kahoot.

Kahoot - безкоштовний онлайн-сервіс зі створення тестів, опитувань і вікторин [14]. На питання вікторини, створені бібліотекарами, учасники відповідають зі своїх смартфонів/планшетів, підключених до Інтернет.

Сервіс дозволяє підготувати «кахути» (так називаються створені роботи) чотирьох видів: тест-вікторина для визначення рівня знань - Quiz, дискусія чи презентація ідеї та отримання зворотного зв'язку щодо неї - Discussion, анкетування, вивчення думки з певного питання - Survey, гра із завданнями на послідовність дій чи елементів - Jumble.

Першою на платформі Kahoot була підготовлена ювілейна вікторина до 50-річчя Київського національного університету культури і мистецтв.

Наступною стала вікторина, розроблена до 205-річниці від дня народження Тараса Шевченка. Передувала їй інтерактивна лекція Людмили Касян, провідного наукового співробітника Центрального державного кінофотофоноархіву України ім. Г. Пшеничного - «Образ і творчість Т. Г. Шевченка в аудіовізуальних документах» за матеріалами якої і були підготовлені питання.

Веб-вікторина «Шевченко. Бажання життя» (Рис. 1, Рис. 2) складається iз 15 питань, кожне ілюстроване ретельно підібраним зображенням.

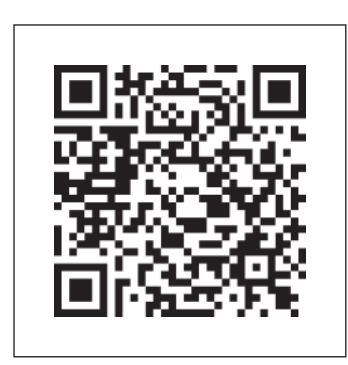

Puc. 1
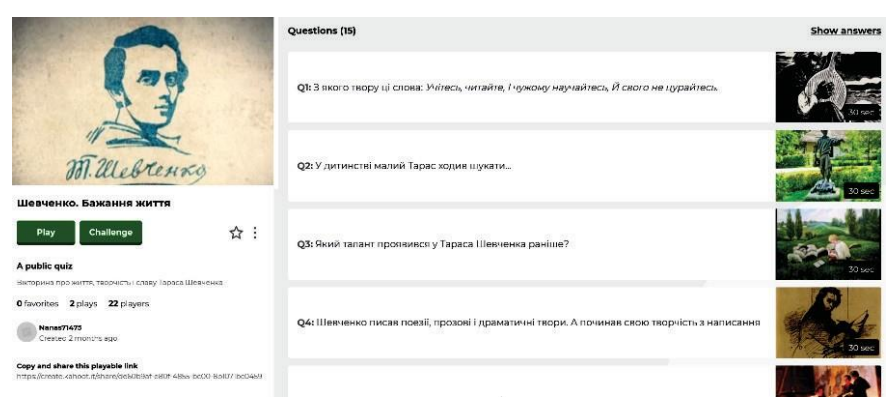

Puc. 2 
Проведення веб-вікторини мало декілька етапів: вступ (Introduction), оголошення завдання і правил (Task), процес виконання завдань (Process), оцінка проміжних результатів (Evaluation), підсумки, нагородження переможців, збереження статистики гри (Conclusion).

У вступній частині модератор відкрила на великому екрані ігрову кімнату, де свої nickname, за допомогою автоматично генерованого програмою PINкоду, зареєструвало 18 гравців. Тобто кожен грав за себе.

На екрані з'являлися питання вікторини та варіанти відповідей, позначені кольоровими геометричними фігурами. Учасники правильні відповіді позначали на своїх мобільних телефонах (Рис. 3).



Puc. 3

Щоб підвищити змагальний ефект, темп гри регулювався таймером із 30 секундним періодом, відведеним на відповідь. Налаштування були виконані таким чином, що додаткові бали гравці отримували за швидкість відповіді. Чим швидше учасники відповідали, тим більше балів отримували. Після кожного питання показувався поточний рейтинг гри: кількість правильних/не правильних відповідей, лідери (змінювалися у процесі проходження вікторини). Коли вікторина була пройдена, на екрані з'явився подіум, де демонструвалися nickname переможців та загальна кількість набраних ними балів.

3 досвіду проведення веб-вікторин можна констатувати, що студенти із задоволенням беруть у них участь, сприймаючи гейміфікацію як виклик, що ставить чіткі цілі, має встановлені правила і обмеження для їх досягнення. Найчастіше, учасники гри обирають активну роль - лідера, дослідника. Всі ці складові підвищують мотивацію до вивчення дисципліни і ефективного запам'ятовування навчальної інформації.

На завершення, пропоную зіграти в гру «Пошук слів». На Рис. 4 наведено розглянуті у статті основні терміни гейміфікації та прізвища авторів-дослідників використання ігрових механік. Завдання - знайти одне прізвище, згадуване у тексті, але відсутнє у хмарі. 


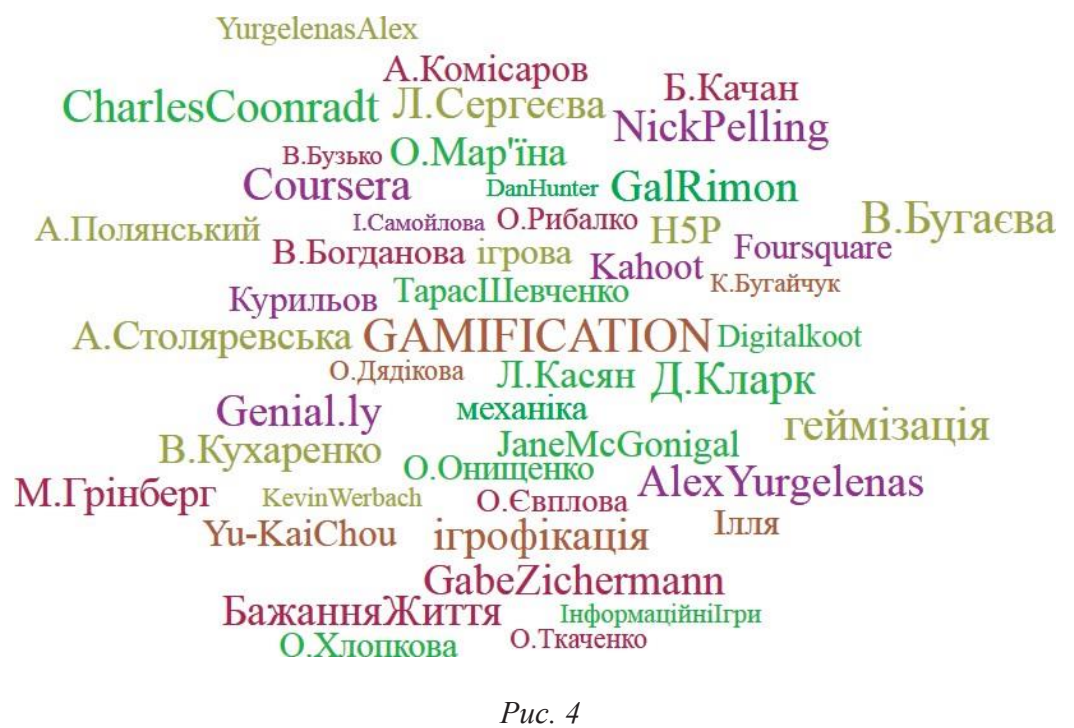

Висновки. Підсумовуючи зазначимо, що ігри угамовують одну із психологічних потреб людей: впевненість у своїх знаннях чи досвіді; у тому, що $\epsilon$ сфери, де вони більш вправні, ніж інші. Ігрові технології гейміфікаціїзастосовуються у різних галузях знань: від бізнесу, управління персоналом, 3МI, охорони здоров'я до освіти і культури. Під час гри формується мотивація перемоги та спільної діяльності.

Основою гейміфікації є ідея використання ігрового підходу для перетворення процесу навчання чи рутинної роботи на більш захопливий і цікавий.

Головним завданням бібліотек у цифровому суспільстві $є$ адаптація інноваційних технологій і методик до використання у бібліотечній діяльності; пошук сучасних моделей організації комунікаційного простору.

Застосування гейміфікації у бібліотечній галузі має переваги, серед яких: масштабність заходів; налагодження нових форм комунікації з користувачами; демонстрація креативності, цінності бібліотеки як майданчика творчого спілкування; формування кола «друзів бібліотеки», готових брати участь у підготовці і проведенні інформаційних, просвітницьких, музично-поетичних заходів; заохочення до пізнання культури і мистецтва України та світу тощо.

Технології геймізації ефективно сприяють набуттю нових знань, компенсують перевантаження інформацією шляхом емоційного та психологічного відпочинку. Застосування гейміфікації у бібліотечній діяльності сприяє розвитку цілеспрямованості, інтелектуальної активності, комунікації та командної взаємодії. 


\section{Список використаної літератури}

1. Вербах К. Вовлекай и властвуй. Игровое мышления на службе бизнеса [Текст] / К. Вербах, Д. Хантер ; пер. с англ. А. Кардаш. - М. : «Манн, Иванов и Фербер», 2015. - 224 с.

2. Евплова E. В. Геймификация как средство повышения мотивации к обучению [Текст] / Е. В. Евплова // Одинцовские чтения. - 2013. - № 2. - С. 48-51.

3. Зикерманн Г. Геймификация в бизнесе: как пробиться сквозь шум и завладеть вниманием сотрудников и клиентов [Текст] / Г. Зикерманн, Д. Линдер. - М. : Манн, Иванов и Фербер, 2014. - 272 с.

4. Корнилов Ю. В. Геймификация и веб-квесты: разработка и применение в образовательном процессе / Ю. В. Корнилов, И. П. Левин // Современные проблемы науки и образования : электрон. науч. журн. 2017. - № 5. - Электрон. дан. - Режим доступа: https://bit.ly/2Y3GNEn (дата обращения: 25.07.2019). Загл. с экрана.

5. Курылев И. Gamification Now! : «Суть игрофикации в том, чтобы дать пользователю то, что ему нужно» : интервью / И. Курылев. - Электрон. дан. - Россия, 2016, 8 июля.- Режим доступа: https://bit. 1y/2LIvpY6 (дата обращения: 25.07.2019). - Загл. с экрана.

6. Макгоннигал Д. Реальность под вопросом : почему игры делают нас лучше и как они могут изменить мир [Текст] / Д. Макгонигал ; пер. с англ. Н. Яцюк. - М. : Манн, Иванов и Фербер, 2018. - 384 с.

7. Мар '̈̈на О. Ю. Інформаційно-комунікаційна взаємодія як фактор розвитку регіональних бібліотечних систем : дис. канд. наук із соц. комунікацій : 27.00 .03 [Текст] / О. Ю. Мар’їна. - Харків, 2011. - 224 с.

8. Мосин А. ...Плюс геймификация всей страны? / А. Мосин // Банки Украины. - Электрон. дан. - Украина, 2012, 2 нояб.- Режим доступа: https://bit.ly/2Mmc6DF (дата обращения: 25.07.2019). - Загл. с экрана.

9. Онищенко О. Проблеми адаптації бібліотек до умов цифрової культури [Текст] / О. Онищенко // Бібл. вісн. - 2015. - № 6. - С. 3-7.

10. Самойлова I. Гейміфікація - один 3 трендів сучасної освіти : презентація / I. Самойлова // In : SlideShares. - Електрон. дані. - Україна, 2014, груд. - Режим доступу: https://bit.ly/2YnoB8m (дата звернення: 25.07.2019). - Загол. з екрана.

11. Сергеєва Л. Гейміфікація: ігрові механіки у мотивації персоналу / Л. Сергеєва // Theory and methods of educational management. - 2014. - № 2 (14). - Електрон. дані. - Режим доступу: https://bit.ly/2Z6L6vc (дата звернення: 25.07.2019). - Загол. з екрана.

12. Ткаченко О. Гейміфікація освіти : формальний і неформальний простір / О. Ткаченко // Актуальні питання гуманітарних наук. - 2015. - Вип. 11. - С. 303-309.

13. Юргеленас A. Что такое геймификация? / А. Юргеленас // Стратегический Контент Маркетинг. Электрон. дан. - Россия, 2017, 11 янв. - Режим доступа: https://bit.ly/32SELWr (дата обращения: 27.07.2019). - Загл. с экрана.

14. Micklethwait Ja. Kahoot! Joins the Microsoft Partner Network and adds integration with Microsoft Teams / Ja. Micklethwait // Kahoot! All Rights Reserved. - Електрон. дан. - [Norway ; UK ; USA], 2019, June 24. Режим доступу: https://kahoot.com/ (дата звернення: 25.07.2019). - Загол. з екрана.

15. Zichermann $G$. The purpose of gamification. A look at gamification's applications and limitations / G. Zichermann // Radar : insight, analysis, and research about emefging technologies. - Електрон. дані. 2011, april 26. - Режим доступу: https:/oreil.ly/2K5Rk8x (дата звернення: 25.07.2019). - Загол. $з$ екрана.

\section{References}

[1]. Verbakh K., Khanter D. Vovlekai i vlastvui. Igrovoe myshleniia na sluzhbe biznesa [For the Win: How Game Thinking Can Revolutionize Your Business]. Moskva, 2015, 224 p.

[2]. Evplova E. V. Geimifikatciia kak sredstvo povysheniia motivatcii k obucheniiu [Gamification as a means of increasing motivation to learn]. Odintcovskie chteniia [Odintsovo read]. 2013, no. 2, pp. 48-51.

[3]. Zikermann G., Linder D. Geimifikatciia v biznese: kak probitsia skvoz shum i zavladet vnimaniem sotrudnikov $i$ klientov [Gamification in business: how to break through the noise and capture the attention of employees and customers]. Moskva, 2014, 272 p.

[4]. Kornilov Iu. V., Levin I. P. Geimifikatciia i veb-kvesty: razrabotka i primenenie v obrazovatelnom protcesse [Gamification and web quests: development and application in the educational process]. Sovremennye problemy nauki i obrazovaniia [Modern problems of science and education]. 2017, no. 5. Available at: https:// bit.ly/2Y3GNEn.

[5]. Kurylev I. Gamification Now!: Sut igrofikatcii v tom, chtoby dat polzovateliu to, chto emu nuzhno [Gamification Now!: The essence of gamification is to give the user what he needs]. Rossiya, 2016, 8 iyulya. Available at: https://bit.ly/2LIvpY6. 
[6]. Makgonnigal D. Realnost pod voprosom. Pochemu igry delaiut nas luchshe i kak oni mogut izmenit mir [Reality in question. Why games make us better and how they can change the world]. Moskva, 2018, 284 p.

[7]. Marina O. Yu. Informatsiino-komunikatsiina vzaiemodiia yak faktor rozvytku rehionalnykh bibliotechnykh system [Information and communication interaction as a factor for the development of regional library systems]. Kharkiv, 2011, 224 p.

[8]. Mosin A. ...Plius geimifikatciia vsei strany? [Plus gamification of the whole country?]. Banki Ukrainy [Ukrainian banks]. Ukraina, 2012, 2 noyabrya. Available at: https://bit.ly/2Mmc6DF.

[9]. Onyshchenko O. Problemy adaptatsii bibliotek do umov tsyfrovoi kultury [Problems of adaptation of libraries to the conditions of digital culture]. Bibliotechnyi visnyk [Library Bulletin]. 2015, no. 6, pp. 3-7.

[10]. Samoilova I. Heimifikatsiia - odyn z trendiv suchasnoi osvity [Gameimification is one of the trends of modern education]. In: SlideShares. Ukraina, 2014, hruden. Available at: https://bit.ly/2YnoB8m.

[11]. Serheieva L. Heimifikatsiia: ihrovi mekhaniky u motyvatsii personalu [Gameplay: game mechanics in the motivation of the staff]. Theory and methods of educational management. 2014, no 2 (14). Available at: https:// bit.ly/2Z6L6vc

[12]. Tkachenko O. Heimifikatsiia osvity : formalnyi i neformalnyi prostir [Education Geymification: formal and informal space]. Aktualni pytannia humanitarnykh nauk [Actual questions of the humanities]. 2015, no. 11, pp. 303-309.

[13]. Yurgelenas A. Chto takoe geimifikatciia? [What is gamification?]. Strategicheskiy Kontent Marketing [Strategic Content Marketing]. Rossiiya, 2017, 11 yanvarya. Available at: https://bit.ly/32SELWr.

[14]. Micklethwait Ja. Kahoot! Joins the Microsoft Partner Network and adds integration with Microsoft Teams. Kahoot! All Rights Reserved. Norway; UK; USA, 2019, June 24. Available at: https://kahoot.com/.

[15]. Zichermann G. The purpose of gamification. A look at gamification's applications and limitations. Radar: insight, analysis, and research about emefging technologies. 2011, april 26. Available at: https://oreil. ly/2K5Rk8x.

Надійшла 08.08.2019 p.

Скаченко Е. А.,

заведующая сектором методической работы

Научной библиотеки Киевского национального

университета культуры и искусств

ул. Евгения Коновальца, 36, Киев, 01133, Украина

тел.: (044) 5299834

e-mail: skachenko.nana@ukr.net

ORCID: 0000-0003-3827-5985

\section{ИСПОЛЬЗОВАНИЕ ИГРОВОЙ МОДЕЛИ ГЕЙМИФИКАЦИИ В СОЦИОКУЛЬТУРНОЙ ДЕЯТЕЛЬНОСТИ БИБЛИОТЕК}

Статья актуализирует тренд использования игровых механик в социокультурной деятельности библиотек.

Целью работы является исследование основных форм, функций, характерных особенностей технологии геймификации (от англ. Gamification, игрофикация), которая мотивируя к участию в игре превращает скучные процессы обучения или деятельности на привлекательные, интересные и познавательные; изучение перспектив использования игровой механики в социально-культурной деятельности библиотек.

В своей работе автор использовал методы анализа, описания, обобщения, систематизации и других методов научных исследований. 
В статье назван круг украинских и зарубежных исследователей, применяющих игровые технологии, анализируются основные аспекты методологии, стратегии и мотивации процесса игры.

В результате анализа источников, геймификацию библиотечной деятельности предлагается рассматривать как использование игровых практик, техник, компьютерных и настольных игр с просветительской целью, целями, задачами.

На основе практического опыта научной библиотеки КНУКИИ описано использование игровых моделей игрофикации при проведении Информационных игр на тему информационной грамотности, которые включали проведение интеллектуальных викторин, игр и практических заданий по тематике работы отделов библиотеки. При разработке сценария информационных игр учитывались основные аспекты геймификации: динамика, механика, эстетика, социальное взаимодействие.

В результате изучения библиотечного опыта и специфики интерактивной платформы Kahoot для создания викторин, автором предложены перспективы применения геймификации в социокультурной деятельности библиотек.

Основными преимуществами использования игр в деятельности библиотек, по мнению исследователя, являются: творчество и нестандартная деятельность, установление новых форм общения с пользователями формирование круга «друзей библиотеки».

Ключевые слова: геймификация, игровая механика, библиотеки, информационные игры, веб-викторины, Kahoot.

\section{Skachenko O. O.,}

Head of the methodological work sector

Scientific Library of the Kiev National

University of Culture and Arts

36 Yevhen Konovalets Street, Kyiv, 01133, Ukraine

tel.: (044) 5299834

e-mail: skachenko.nana@ukr.net

ORCID: 0000-0003-3827-5985

\section{USING THE GAME MODEL OF GAMEPLAY IN THE SOCIO-CULTURAL ACTIVITY OF LIBRARIES}

\section{Summary}

The purpose of the article is to study the functions, the main forms, the characteristic features of gamification technology, which motivates to participate in the game, transforms boring learning or routine activities into attractive, interesting and cognitive; prospects of the use of game mechanics of gaming in the socio-cultural activities of libraries.

In his work the author used methods of analysis, description, generalization, systematization and other methods of scientific research.

The article names the range of Ukrainian and foreign researchers applying game technologies, analyzes the basic aspects of methodology, strategy, and motivation for the process of gaming. 
As a result of the analysis of sources, gameplay in the library is proposed to be considered as the use of gaming practices, techniques, computer and desktop games with an educational purpose, goals and objectives.

Based on the practical experience of the scientific library KNUCA described the use of game gaming models during the conduct of Information games on informational literacy, which provided for the conduct of intellectual quizzes, game and practical tasks in the subject of library departments.

The development of the script and the tasks of the Information games took into account the main aspects of gameplay: dynamics, mechanics, aesthetics, social interaction.

As a result of studying library experience and specifics of the interactive platform Kahoot for the creation of quizzes, proposed the prospects of application gamification in the socio-cultural activities of libraries.

According to the researcher, the main advantages of using gaming in the activities of libraries are: creativity and non-standard activities, establishing new forms of communication with users; forming a circle of "friends of the library".

Keywords: gameplay, gamification, game mechanics, libraries, informational games, web quizzes, Kahoot. 